\title{
Effects of Organic Materials Obtained from Different Tree Species on Some Chemical Parameters of Water Quality (Study Case of Andirin- Akifiye Forest Management Unit)
}

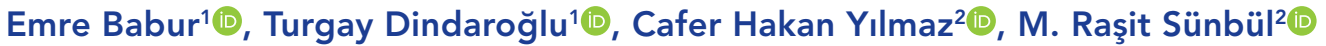 \\ Cite this article as: Babur, E., Dindaroglu, T., Yilmaz, C.H., \& Sunbul, R. (2021). Effects of organic materials obtained from different tree species on \\ some chemical parameters of water quality (study case of Andirin-Akifiye Forest Management Unit). Aquatic Sciences and Engineering, 36(1), 15-21.
}

ORCID IDs of the author: E.B. 0000-0002-1776-3018; T.D. 0000-0003-2165-8138; C.H.Y. 0000-0003-3680-453X R.S. 0000-0003-2093-9659

${ }^{1}$ Kahramanmaras Sutcu Imam University, Faculty of Forestry, Department of Soil and Ecology, Kahramanmaraş, Turkey

${ }^{2}$ East Mediterranean Transitional Zones Agricultural Research Institute, Kahramanmaraş, Turkey

\section{Submitted:}

04.04.2020

Revision Requested:

01.06.2020

Last Revision Received:

01.06.2020

Accepted:

10.06.2020

Online published:

21.10.2020

Correspondence:

Emre Babur

E-mail:

emrebabur@ksu.edu.tr

(C) Copyright 2021 The Author(s) Available online at

https://dergipark.org.tr/ase

\begin{abstract}
Mineral substance concentrations are very important in terms of the levels of chemical quality in drinking water. A highly important source of minerals in water comes from the litter layer of the forest floor which is also a source of organic matter. This research investigates the contribution of organic litter formed in pure pine, cedar and beech forests to the quality parameters of water in the Andirin District of Kahramanmaraş province. A total of 90 organic matter samples were systematically collected from three different forest ecosystems. Some chemical properties of water solution were obtained from the organic matter using the ICP-OES device. This revealed that aluminum, boron, zinc, iron, cadmium, calcium, cobalt, magnesium, manganese, nickel and potassium parameters were present in the water. In addition, $\mathrm{pH}, \mathrm{EC}$ and temperature measurements were taken. The results revealed lower amounts of chemicals in the waters obtained from the dead vegetation covers of the beech forests, showing elements such as aluminum, iron, magnesium, cobalt, and nickel levels to be $0.146 \mathrm{mg} ; 0.114 \mu \mathrm{g} ; 5.54 \mathrm{mg} ; 0.0006 \mu \mathrm{g}$ and $0.0054 \mu \mathrm{g}$, respectively, compared to waters obtained from cedar and pine forest ecosystems. It was found that different organic materials had significantly different mineral concentrations affecting the chemical quality of the water. However, waters affected by the dead vegetation cover of the forest ecosystem were determined to comply with the standards of drinking and irrigation water according to current regulations.
\end{abstract}

Keywords: Forest ecosystems, forest litter layer, hydrological function, water quality

\section{INTRODUCTION}

One of the most important environmental problems in the world is water scarcity and water pollution (Costanza \& Jorgensen, 2002; Bulut, Atay, Uysal, Köse, \& Çınar, 2010; Tokatli, Solak, \& Yılmaz, 2020). Forest ecosystems play an active role in solving both of these problems. These roles, undertaken by the ecological functions of forests, can be protected by increasing social awareness on this issue. Blanco \& Lo (2012) defined forests as open systems with social, economic and ecological functions. Plant species, soil and climate factors constitute the main components of these relationships in ecosys- tems (Kantarcı, 2003). There are strong relationships and interactions between forests and drinking and irrigation water quality (Altun, Kezik, Kara, \& Babur, 2016). In addition to meeting the demand for drinking and irrigation water as a hydrological function, forest ecosystems also contribute to wastewater treatment (Gray \& Deneke, 1986; Altun et al., 2016). In a catchment basin, land use types (forest, pasture, agriculture, settlement, etc.), vegetation types (coniferous or leafy tree species, meadow, openness), geology, climate, physical, chemical, and biological soil properties, etc. all affect the quantity and quality of water (Gerrits, Pfister, \& Savenije, 2010; Altun et al., 2016; Babur \& Kara, 2017). 
Forest ecosystems allow quality minerals to reach underground water by letting rainwater flow into surface water by infiltration, without letting it flow into the surface and thereby into dead vegetation and soil. Altun et al. (2016) stated that forests play an important role in providing quality water and the cost of treatment is lower in waters supplied from forests. Particularly in forests, the organic material that covers the soil's surface absorbs even the most severe rains, prevents superficial erosion and contributes positively to the mineral composition of the water. In a study by Özhan (2004), the needle leaf litter of a forest containing decayed mull or more types of humus can easily be filtered by draining heavy rain $(150 \mathrm{~mm} / \mathrm{h})$ into the soil. It is of great importance in the infrastructure and installation stages to identify the resources from which drinking-irrigation water will be provided and to ensure its sustainability. Of particular importance is the need for drinking water dams to be installed far away from anthropogenic effects, in the upper parts of the catchment basin, and near the forest and pasture borders. It is well known that there are important differences in water quality and quantity of micro basins, which consist of different types of land use, belonging to drinking dams installed on the upper parts of the basin (Tobon-Marin, Bouten, \& Sevink, 2000; Gerrits et al. 2010; Altun et al. 2016). The studies which have so far been conducted generally show the effect of rainfall on forest ecosystems with different coverage rates: surface flow rate, infiltration capacity, groundwater, and amount of interception. However, there has not yet been enough study on the interaction of the rain reaching the stand surface through organic matter and mixing with the soil, nor on that obtained from groundwater (Li, Niu, \& Xie, 2013).

Organic matter is an organic composite formed by the accumulation of the components of plants such as dead leaves, branches, shells, flowers, and cones on the soil surface. The role of organic matter in forests is of great importance in terms of substance cycles in the ecosystem. Thus, organic matter contributes to the hydrological cycle and the food cycle of the ecosystem, it provides protection of soils against erosion, reducing soil temperature and decreasing the amount of evaporation, and it is a nutrient source of soil organisms enabling slow infiltration of precipitation into the soil (Bussiere \& Cellier, 1994; Muria, 2000; Sato, Kumagai, Kume, Otsuki, \& Ogawa, 2004). It plays an important role in changing the physical, chemical and biological properties of the soil by mixing with the soil as a result of the decomposition of the litter layer over time (Sayer, 2006; Kara, Babur, Altun, \& Seyis, 2016; Babur, 2019; Babur \& Dindaroğlu, 2020). In addition, besides forming the decomposed vegetation cover, and thus providing food and energy sources such as carbon, nitrogen, phosphorus and other elements for living creatures in rivers and dams, organic matter in forests is also known to improve the quality of groundwater as a function of the aquatic ecosystem (Cummins et al., 1983; Dorney, 1986; Meyer, Wallace, \& Eggert, 1998). Although forest ecosystems and organic matters are very important in terms of the supply of drinking water from freshwater sources, insufficient measurement and evaluation techniques have led to a poor understanding of the role of dead vegetation covers in the hydrological cycle (Lundberg, Eriksson, Halldin, Kellner, \& Seibert, 1997; Gerrits, Savenije, Hoffmann, \& Pfister, 2007). Studies have been conducted on the maximum water holding capacities and interception capacities of dead vegetation covers (Pitman, 1989; Putuhena \& Cordery, 1996; Sato et al. 2004). Another study, an investigation was made into the effects of different types of organic matter on the drinking and irrigation water quality of dams (Duan, Amon, \& Brinkmeyer, 2014).

This study was carried out in the Andirin-Akifiye Forest management Unit of Kahramanmaraş Province to investigate the effects of organic matter obtained from different forest ecosystems on some water quality parameters.

\section{MATERIALS AND METHODS}

This study was carried out in the even aged pure larch, cedar and beech forests within the boundaries of the Andirin-Akifiye Forest Management Unit in Kahramanmaraş Regional Directorate of Forestry (Figures 3a, 3b and 3c). The aim of this study was to determine the effects of the dead vegetation cover under different forest tree species (pure beech, cedar and black pine stands) on water quality. For this reason, we selected close forest sections 115, 116, 132 and 134 where stand establishment, closure, stand age, geological, climatological and geomorphological features were similar. The research area covers a total area of $\sim 100$ hectares in typical karstic mountain basins in the rugged topography of the Mediterranean Region (36 $17^{\prime} 00^{\prime \prime}-36^{\circ} 18^{\prime} 40^{\prime \prime} \mathrm{E}$ longitude, $37^{\circ} 43^{\prime} 05^{\prime \prime}-37^{\circ} 44^{\prime} 10^{\prime \prime} \mathrm{N}$ latitudes). The research area is approximately $90 \mathrm{~km}$ from Kahramanmaraş Province and the average elevation of the area is $1500 \mathrm{~m}$, with the general aspect being south facing and the average slope being a $45 \%$ incline. The general location study sites are shown in Figure 1 and a forest stand types map is shown in Figure 2.

Silvicultural properties (closure and stand type) of beech, cedar, and pine species are given in Table 1.

\section{Field study}

During the sample collection, care was taken not to mix litter layers with mineral soil. In order to prevent the samples from losing moisture, they were placed in polyethylene bags (Figures $4 a-c$ ).

\section{Laboratory analysis}

A suspension of 1/20 (organic matter / pure water) was prepared using powdered samples of different types, which were prepared

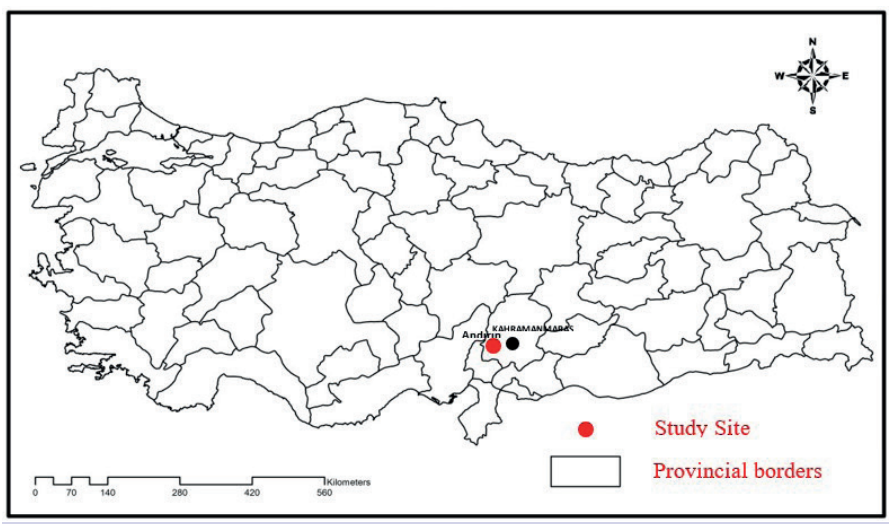

Figure 1. Location of the study area on the map of Turkey. 


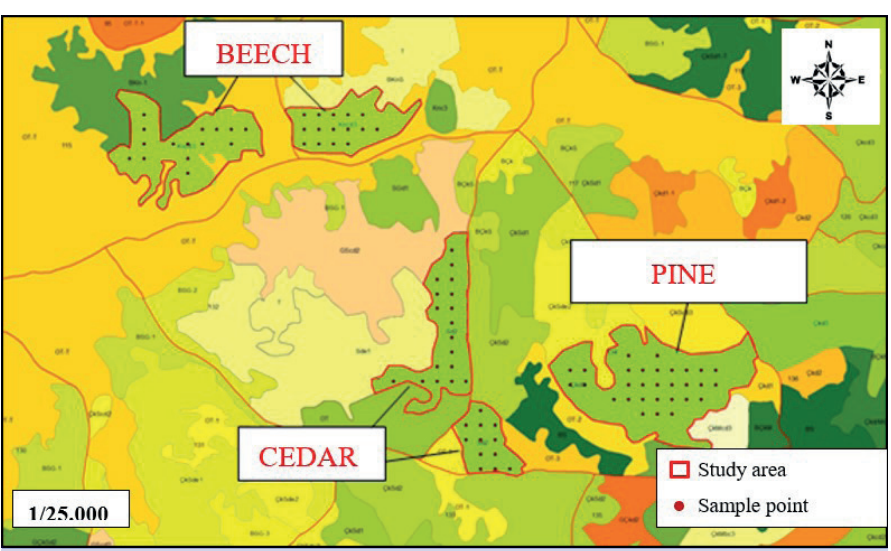

Figure 2. The location of beech, cedar and black pine stands on the Forest Management map (Anonymous, 2014).

Table 1. Silvicultural characteristics in stands of research area (Anonymous 2014).

\begin{tabular}{lcc|c}
\hline Tree Species & Stand Type & \multicolumn{2}{c}{ Closure \% } \\
\hline Beech & Kncd3 & 3 & $70-100$ \\
Cedar & Sd2-3 & 3 & $70-100$ \\
Pine & Çkd3 & 3 & $70-100$
\end{tabular}

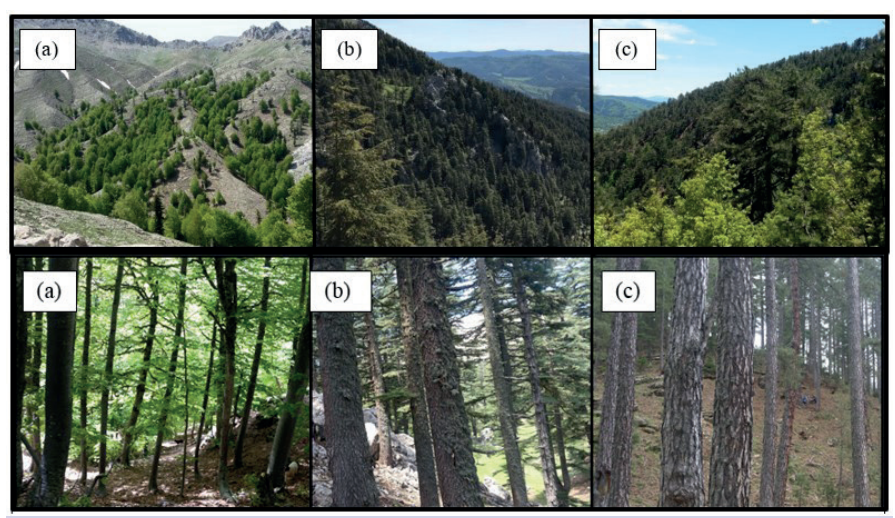

Figure 3. View of (a) beech, (b) cedar and (c) pine stands in the research areas (Photo: Emre Babur 2017).

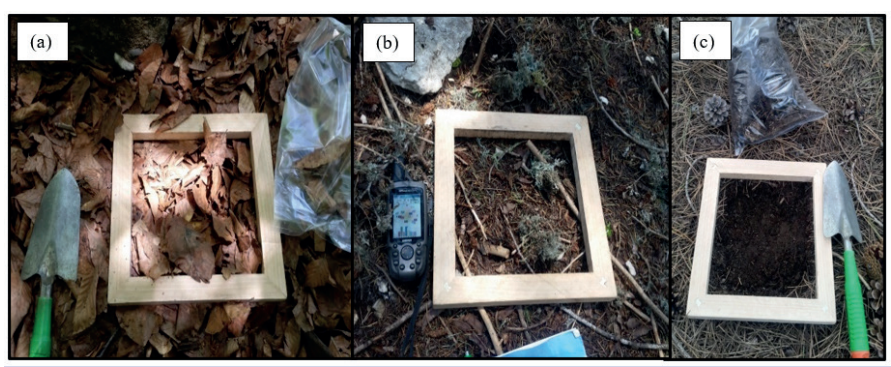

Figure 4. Collection of organic matter samples (a) beech, (b) cedar and (c) pine (Photo: Emre Babur 2017). by sieving through a $1 \mathrm{~mm}$ sieve, being shaken in a shaker for 30 minutes and then resting for 24 hours. All samples were filtered through a membrane using Whatman Grade 42 paper $(2.5 \mu \mathrm{m}$ pore size) and then stored at $4{ }^{\circ} \mathrm{C}$ before analysis. Temperature, $\mathrm{pH}$, and Electrical Conductivity $(\mathrm{EC})$ were measured using the obtained saturation with a thermometer, $\mathrm{pH}$ meter and $\mathrm{EC}$ meter, respectively (Gülçür, 1974). The Calibration standards for determined elements were prepared using single element NIST traceable standards. All measurements were performed using an Agilent 5100 SVDV ICP-OES configured with an SPS 4 auto-sampler by preparing high purity standards and stock solutions of different concentrations for 11 elements: $\mathrm{Al}, \mathrm{B}, \mathrm{Zn}, \mathrm{Fe}, \mathrm{Cd}, \mathrm{Ca}$, $\mathrm{Co}, \mathrm{Mg}, \mathrm{Mn}, \mathrm{Ni}$ and $\mathrm{K}$ (EPA, 2001). This instrument contains Dichroic Spectral Combiner (DSC) technology and captures the axial and radial viewings of the plasma in one reading. In total, 16 Multi-elemental calibration standards, ranging from $0.005 \mathrm{ppm}$ to $100 \mathrm{ppm}$, were prepared. All calibration standards, Quality Control $(\mathrm{QC})$ checks, and internal standards were prepared and matrix matched with 7\% $\mathrm{HNO} 3+3 \%$ ethanol (Anonymus, 2017).

\section{Statistical analysis}

ANOVA and Duncan tests were performed using the SPSS 15.0 program on the mineral substance concentration values determined as a result of some chemical analyses on water samples obtained from 90 organic litter layer samples collected from systematically determined points from different forest ecosystems.

\section{RESULTS AND DISCUSSION}

Average values and standard errors of some chemical quality parameters of the water samples are shown in Table 2. The values determined as a result of the study were compared with the drinking water quality standards set by the Turkish Standards Institute (TS-266) which produced some regulations such as Regulation on Control of Water Pollution, Surface Water Quality Management Regulation, Recommended Value, Maximum Permissible Value and Regulation on Waters for Humanitarian Consumption.

Extracts prepared from different organic material were measured under laboratory conditions, and there was no statistical difference between the average temperature values. The lowest water temperature $\left(21.0^{\circ} \mathrm{C}\right)$ was found in dead vegetation covers of beech extract, while the highest was found in black pine extract at $21.5^{\circ} \mathrm{C}$ (Table 2 ).

In terms of temperature, according to the relevant regulations, extracts were included in Class I, and extracts according to TS266 were included in the recommended values (Table 3). Since water temperature is effective in the physical, chemical and biological properties of water, it directly affects the water quality (Çetinkaya, 2003).

Levels of $\mathrm{pH}$ decrease with the increase of hydrogen ion concentrations in waters (acidic waters), while these levels rise with the decrease of this concentration (basic waters) (Göksu, 2003). In the $\mathrm{pH}$ measurements made in the extracts obtained, the highest $\mathrm{pH}$ average value was found to be 7.40 in beech water and the lowest $\mathrm{pH}$ value was 6.28 in pine water (Table 2). The $\mathrm{pH}$ values in beech and cedar waters, according to RCWP and SWOMR, were Class I and II respectively, while in pine water it was class III. 
Table 2. Some measured water quality parameters.

\begin{tabular}{|c|c|c|c|}
\hline \multirow{2}{*}{ Physical and inorganic-chemical parameters } & \multicolumn{3}{|c|}{ Source of organic litter } \\
\hline & Beech & Pine & Cedar \\
\hline Temperature $\left({ }^{\circ} \mathrm{C}\right)$ & $21.0 \pm 0.02 \mathrm{a}$ & $21.5 \pm 0.04 a$ & $21.2 \pm 0.01 \mathrm{a}$ \\
\hline $\mathrm{pH}\left(\mathrm{H}_{2} \mathrm{O}\right)$ & $7.40 \pm 0.54 b$ & $6.28 \pm 0.03 \mathrm{a}$ & $7.37 \pm 0.33 b$ \\
\hline Electrical conductivity ( $\mu \mathrm{S} \mathrm{cm}^{-1}$ ) & $364.2 \pm 21.13 b$ & $428.75 \pm 36.17 a$ & $396.38 \pm 32.17 a$ \\
\hline Aluminum (mg Al / L) & $0.146 \pm 0.02 \mathrm{a}$ & $0.688 \pm 0.11 b$ & $0.534 \pm 0.21 b$ \\
\hline Zinc ( $\mu g$ Zn / L) & $0.0288 \pm 0.00 \mathrm{a}$ & $0.0506 \pm 0.01 b$ & $0.0388 \pm 0.01 \mathrm{ab}$ \\
\hline Iron ( $\mu \mathrm{g} \mathrm{Fe} \mathrm{/} \mathrm{L)}$ & $0.114 \pm 0.01 a$ & $0.380 \pm 0.04 b$ & $0.111 \pm 0.03 a$ \\
\hline Cadmium ( $\mu \mathrm{g} \mathrm{Cd} / \mathrm{L}$ ) & $0.002 \pm 0.00 \mathrm{a}$ & $0.002 \pm 0.00 \mathrm{a}$ & $0.003 \pm 0.00 \mathrm{a}$ \\
\hline Calcium (mg Ca $+2 / L)$ & $29.83 \pm 2.02 \mathrm{a}$ & $43.30 \pm 2.39 b$ & $61.10 \pm 5.71 c$ \\
\hline Cobalt ( $\mu \mathrm{g}$ Co / L) & $0.0006 \pm 0.00 a$ & $0.0013 \pm 0.00 \mathrm{a}$ & $0.0014 \pm 0.00 \mathrm{a}$ \\
\hline
\end{tabular}

Table 3. Regulations about Water Quality Parameters (Anonim, 2016a; 2016b; 2016c; TSE, 1997).

\begin{tabular}{|c|c|c|c|c|c|c|c|}
\hline \multirow{2}{*}{$\begin{array}{l}\text { Water Quality Parameters } \\
\text { A) Physical and chemical parameters }\end{array}$} & \multicolumn{4}{|c|}{$\begin{array}{c}\text { RCWP, SWQMR } \\
\text { Water Quality Classification }\end{array}$} & \multicolumn{2}{|c|}{ TS-266 } & \multirow{2}{*}{ RWHC } \\
\hline & I & II & III & IV & RV & MVP & \\
\hline 1) Temperature $\left({ }^{\circ} \mathrm{C}\right)$ & 25 & 25 & 30 & $>30$ & 12 & 25 & - \\
\hline 2) $\mathrm{pH}$ & $6.5-8.5$ & $6.5-8.5$ & $6.0-9.0$ & $>6.0-9.0$ & $6.5-8.5$ & $6.5-9.2$ & $\leq 6.5-9.5 \leq$ \\
\hline 3) Conductivity ( $\mu \mathrm{s} / \mathrm{cm}$ ) & - & - & - & - & 400 & 2000 & 2500 \\
\hline \multicolumn{8}{|l|}{ B) Inorganic contamination parameters } \\
\hline 1) Aluminum (mg Al / L) & 0.3 & 0.3 & 1 & $>1$ & 0.05 & 0.2 & 0.2 \\
\hline 2) Boron ( $\mu g$ B / L) & $1000^{e}$ & $1000^{e}$ & $1000^{e}$ & $>1000^{e}$ & $<1000^{e}$ & 1 & 1 \\
\hline 3) Zinc ( $\mu g$ Zn / L) & 200 & 500 & 2000 & $>2000$ & 100 & 5000 & - \\
\hline 4) Iron ( $\mu \mathrm{g} \mathrm{Fe} \mathrm{/} \mathrm{L)}$ & 300 & 1000 & 5000 & $>5000$ & 50 & 200 & 200 \\
\hline 5) Cadmium ( $\mu \mathrm{g} \mathrm{Cd} \mathrm{/} \mathrm{L)}$ & 3 & 5 & 10 & $>10$ & $\leq 3$ & 10 & 5 \\
\hline 6) Calcium (mg Ca +2 / L) & - & - & - & - & 100 & 200 & - \\
\hline 7) Cobalt ( $\mu \mathrm{g}$ Co / L) & 10 & 20 & 200 & $>200$ & - & - & - \\
\hline 8) Magnesium (mg Mg $+2 / L$ ) & - & - & - & - & 30 & 50 & - \\
\hline 9) Manganese ( $\mu \mathrm{g} \mathrm{Mn+2/L)}$ & 100 & 500 & 3000 & $>3000$ & 20 & 50 & 50 \\
\hline 10) Nickel ( $\mu \mathrm{g} \mathrm{Ni} / \mathrm{L})$ & 20 & 50 & 200 & $>200$ & - & 50 & 20 \\
\hline 11) Potassium (mg K+ / L) & - & - & - & - & 10 & 12 & - \\
\hline
\end{tabular}

RCWP: Regulation on Control of Water Pollution, SWQMR: Surface Water Quality Management Regulation, RV: Recommended Value, MVP: Maximum Value Permissible, RWHC: Regulation on Waters for Humanitarian Consumption

In addition, according to TS-266 and RWHC, beech and cedar water were found to be within the recommended limits for drinking water (Tables 2 and 3).

The total amount of resistance ions in water or the resistance of the solution to electrical conduction is called electrical conductivity (EC) (Güler, 1997). The average electrical conductivity value in the pine water was found to be $428.75 \mu \mathrm{s} / \mathrm{cm}$ and the lowest was found in beech water $(364.2 \mu \mathrm{s} / \mathrm{cm})($ Table 2$)$. Average EC val- ues were within the optimal limits according to TS-266 and RWHC (Table 3).

$\mathrm{Ca}^{+2}, \mathrm{Mg}^{+2}$ and $\mathrm{K}+$ values were analyzed in extracts obtained from organic matter under different forest ecosystems. The highest amount of $\mathrm{Ca}^{+2}$ was in cedar water as $61.10 \mathrm{mg} \mathrm{Ca}^{+2} / \mathrm{L}$ and the lowest was $29.83 \mathrm{mg} \mathrm{Ca}^{+2} / \mathrm{L}$ in the beech water (Table 2). The amount of $\mathrm{Mg}^{+2}$ was found to be the highest in the pine water as $8.70 \mathrm{mg} \mathrm{Mg}^{+2} / \mathrm{L}$ and the lowest in beech water as $5.54 \mathrm{mg} \mathrm{Mg}^{+2} / \mathrm{L}$. 
The highest amount of $\mathrm{K}^{+}$was found in the pine water as $79.20 \mu \mathrm{g}$ $\mathrm{K} / \mathrm{L}$ and the lowest amount in the beech water as $27.76 \mu \mathrm{g} \mathrm{K} / \mathrm{L}$ (Table 2). $\mathrm{Ca}^{+2}, \mathrm{Mg}^{+2}$ and $\mathrm{K}^{+}$values in extract waters were found to be below the limit values in related regulations and TS-266 (Tables 2 and 3). $\mathrm{Ca}^{+2}, \mathrm{Mg}^{+2}$ and $\mathrm{K}^{+}$concentrations should be at determined levels in drinking water for human health. Calcium concentration in drinking water affects blood clotting, the permeability of the cell membrane, muscle movements and neural activity. On the other hand, a daily dose of magnesium should be at least $35 \mathrm{mg}$ in adults for bone, muscle and neural tissues (Güler, 1997). Where there is potassium deficiency, nausea, anorexia, and digestive disorders are observed. Therefore, it has been reported that a daily dose of $2-4 \mathrm{~g}$ of potassium should be taken by adults (Atabey, 2015).

Hardness in water is caused by the concentration of calcium and magnesium ions. Also, hardness refers to the soap's resistance to foaming. American, German, French and Russian hardness are used throughout the world. French hardness is used in Turkey (Rose, 1997). While the average total hardness amount was found to be highest with $68.71 \mathrm{mg} / \mathrm{L}$ in water samples obtained from cedar dead vegetation covers, the lowest hardness level was found in waters obtained from beech dead vegetation covers with $35.37 \mathrm{mg} / \mathrm{L}$. The hardness value of pine water was found to be $52.00 \mathrm{mg} / \mathrm{L}$ (Table 2). Atabey (2015) stated in his study that there are important positive relationships between the hardness of water and cardiovascular diseases.

When the heavy metal contents of the waters obtained from different organic materials are examined, in terms of aluminum, the highest concentration was found to be $0.688 \mathrm{mg} / \mathrm{L}$ in water obtained from pine and the lowest was found to be 0.146 in beech water. In cedar water, this value was found to be $0.534 \mathrm{mg} \mathrm{Al} / \mathrm{L}$. There was a statistically significant difference in Al content ( $p$ $<0.001$; Table 2). If aluminum is taken with drinking water in high amounts, it has been reported that it causes dementia (Atabey, 2015). From the Al values in the waters obtained from the dead vegetation covers of all three forest ecosystems in this study, beech water complies with the TS-266 values, while the others are in the III quality class (RCWP and SWOMR) (Table 3).

In terms of boron concentrations, statistical differences were found in waters obtained from different organic matter types $(p<0.001)$. While beech and pine waters are in the same group, cedar water is in a different group. The highest boron concentration was found in cedar water as $0.112 \mu \mathrm{g} \mathrm{B} / \mathrm{L}$, and the lowest was found in beech water as $0.085 \mu \mathrm{g} \mathrm{B/L}$ (Table 2). Boron performs important tasks in the body. In particular, it helps to protect and effectively use vitamin $D$ in the body with calcium, magnesium and phosphorus minerals. It also contributes to the protection of dental and bone health, and improves mineral brain functions. It supports the work of the estrogen hormone and reduces bone resorption. Another feature of the boron mineral is that it is a natural antibiotic. Boron is widely used in medicine especially in the treatment of osteoporosis, migraine, nervous diseases, fatigue and cancer. The amount of boron that should be taken daily by adults is $13 \mathrm{mg}$ (Anonymous, 2019). In this study, the boron concentration in the waters obtained from different organic matters was below the limit values. Although cedar water is not very rich in boron minerals, necessary for the body's overall health, it can also be taken into the body as an additional nutrient.

In terms of the amount of iron and manganese in the waters studied, $0.14 \mu \mathrm{g} \mathrm{Fe} / \mathrm{L}$ and $0.529 \mu \mathrm{g} \mathrm{Mn+2/L}$ were found in beech water, respectively. In pine water, the finding was $0.380 \mu \mathrm{g} \mathrm{Fe} / \mathrm{L}$ and $0.357 \mu \mathrm{g} \mathrm{Mn}+2 / L$ respectively, and in cedar water it was $0.111 \mu \mathrm{g}$ $\mathrm{Fe} / \mathrm{L}$ and $1.119 \mu \mathrm{g} \mathrm{Mn}^{+2} / \mathrm{L}$ respectively (Table 2 ). No difference was found in terms of manganese concentrations of water obtained from different organic matters ( $p>0.05)$. However, iron concentrations in the waters obtained from different organic materials were found different to be from each other ( $p<0.001)$. Alemdar, Ağaoğlu, Alişarlı, \& Dede (2007) found the following results in a study conducted in the Van province where manganese and iron concentrations were found to be 50 and $200 \mu \mathrm{g} / \mathrm{L}$ in river water, 50 and $150 \mu \mathrm{g} / \mathrm{L}$ in spring waters, and 60 and $100 \mu \mathrm{g} / \mathrm{L}$ in tap water respectively. Another study found manganese 7-15 $\mu \mathrm{g} / \mathrm{L}$, iron 1-180 $\mu \mathrm{g} / \mathrm{L}$ in drinking and tap waters in Van city center (Atasoy, Mercan, Alacabey, \& Kul, 2011), and they found manganese and iron to be 3.88 and $6.67 \mu \mathrm{g} / \mathrm{L}$ in drinking water in the city center of Bitlis. High iron concentration in drinking water causes an increase in the number of microorganisms in network waters (Avşarer, Tüfekçi, Elmaslar, \& Şahin, 2005). While iron excess in the body causes liver failure, low amounts of iron cause jaundice, anemia, shortness of breath and excessive fatigue. Manganese is quite poisonous. In its excess, it causes negative effects on the brain and lungs (Atabey, 2015). The waters we obtained in this study were within the limits in first class water quality in terms of iron and manganese according to the RCWP and SWOMR and below the limits specified in TS-266, and RWHC (Table 3).

In the water obtained in this study from dead vegetation covers under the beech forest ecosystem, zinc, cadmium, cobalt, and nickel values were found to be $0.0288 \mu \mathrm{g} \mathrm{Zn/L,} 0.002 \mu \mathrm{g} \mathrm{Cd} / \mathrm{L}$, $0.0006 \mu \mathrm{g} \mathrm{Co} / \mathrm{L}, 0.0054 \mu \mathrm{g} \mathrm{Ni} / \mathrm{L}$ respectively. In the water obtained from the pine organic litter layer, the levels were $0.0506 \mu \mathrm{g}$ $\mathrm{Zn} / \mathrm{L}, 0.002 \mu \mathrm{g} \mathrm{Cd} / \mathrm{L}, 0.0013 \mu \mathrm{g} \mathrm{Co} / \mathrm{L}, 0.021 \mu \mathrm{g} \mathrm{Ni} / \mathrm{L}$ respectively, and in the water obtained from the cedar dead vegetation cover the levels were $0.0388 \mu \mathrm{g} \mathrm{Zn/L,} 0.003 \mu \mathrm{g} \mathrm{Cd} / \mathrm{L}, 0.0014 \mu \mathrm{g} \mathrm{Co} / \mathrm{L}$, $0.013 \mu \mathrm{g} \mathrm{Ni} / \mathrm{L}$, respectively (Table 2). According to the results of the analysis conducted in drinking and tap water in Van city center, zinc values were $30-400 \mu \mathrm{g} / \mathrm{L}$, nickel values were $12-46 \mu \mathrm{g} / \mathrm{L}$, and cobalt values were $7-14 \mu \mathrm{g} / \mathrm{L}$ (Atasoy et al. 2011). The average zinc concentration in drinking water of Bitlis province was found to be $28.2 \mu \mathrm{g} / \mathrm{L}$ (Kahraman, Alemdar, Alişarlı, \& Ağaoğlu, 2012). In our study, while cobalt, nickel and zinc average values were below the optimal limits according to TS-266, these waters have first class water quality characteristics according to RCWP and SWOMR. Cobalt is found in the component of vitamin B12 and is effective in body's resistance and prevents anemia, provides relief of digestion difficulty, fatigue, and muscle fatigue. Nickel, which has a toxic effect, causes an allergic reaction on the skin. Zinc causes health problems if it is above $3 \mathrm{mg} / \mathrm{L}$ in drinking water (Atabey, 2015).

\section{CONCLUSION}

In summary, different organic materials in forest ecosystems affect water quality at different rates. In addition to the fact that 
people obtain the nutrients necessary for their bodies by eating solid foods, the waters obtained by filtering through organic matter formed under different forest ecosystems also have a huge influence on the body's health, and thus organic matter from forests plays an important part in water production.

The findings of this study into certain chemical properties found in the water which passes through organic material of different types of forest trees show that all of these waters were in the 1st class water quality class according to RCWP and SWOMR, while the $\mathrm{pH}$ value of pine water was found to be water quality class III. Moreover, all these values, except for the pine $\mathrm{pH}$ value, were found to be close to the values specified in RWHC and TS-266 and were within the optimal limits.

The results showed that there are no negative chemical parameters to be found in the drinking water to be supplied from the region. The waters are within the optimal limits according to current regulations. In the future, it is predicted that there will be significant decreases in water potential and quality throughout the world and also in Turkey. Forest ecosystems have great potential in the sustainability of water supply and quality. It is particularly important that the functional efficiency of hydrological function forests should be maintained, and we recommend that the production and silvicultural activities in these areas should be included in forest management plans.

Conflict of interests: The authors have no conflicts of interest to declare.

\section{Ethics committee approval: -}

\section{Funding: -}

Acknowledgments: This study was presented as an oral presentation at the $3^{\text {rd }}$ Water and Health Congress.

Disclosure: This study was presented at the " $3^{\text {rd }}$ International Water and Health Congress will be held $12^{\text {th }}-15^{\text {th }}$ November 2019 in Antalya".

\section{REFERENCES}

Altun. L., Kezik, U., Kara, U. \& Babur, E. (2016). Potential of water purification of macka forest ecosystems in northeastern Turkey. $J$ Environ Prot Ecol, 17(2), 557-565.

Alemdar, S., Ağaoğlu, S., Alişarlı, M. \& Dede, S. (2007). Van bölgesi su kaynaklarında ağır metal kirlilik düzeyleri. Eurasian J Vet Sci, (23), 119-29.

Anonymus. (2014). Andırın Orman İşletme Müdürlüğü, Akifiye Orman Amenajman Planı. Kahramanmraş Orman Bölge Müdürlüğü. Orman Genel Müdürlüğü (2014-2033)

Anonymus. (2016a). "Insani tüketim amaçlı sular hakkında yönetmelik", Sağlık Bakanlığı. R. G. Tarihi: 17.02.2005, R.G. Sayısı: 25730. Ek 1 (Değişik ek: R.G-7/3/2013-28580). (Access Date: 10.08.2019).

Anonymus. (2016b). "Su Kirliliği Kontrolü Yönetmeliği", Çevre ve Orman Bakanlığı, R. G. Tarihi: 31.12.2004, R. G. Sayısı: 25687. Ek 1 (Değişik: R.G.-13/2/2008-26786). (Access Date: 10.08.2019).

Anonymus. (2016c). "Yüzeysel Su Kalitesi Yönetimi Yönetmeliğinde Değişiklik Yapılmasına Dair Yönetmelik", Orman ve Su Işsleri Bakanlığı, R.G. Tarihi: 15.04.2015, R.G. Sayısı: 29327. (Access Date: 10.08.2019).

Anonymus. (2017). https://www.lqa.com/wp-content/uploads/2017/05/ agilent-5110-appnote.pdf
Anonymus. (2019). http://tr.mydearbody.com/mineraller/bor-minerali. html (Access Date: 10.08.2019).

Atabey, E. (2015). Elementler ve Sağlığa Etkileri, Hacettepe Üniversitesi Mezotelyoma ve Medikal Jeoloji Araş. ve Uygulama Merkezi Yayınları, Yayın No: 1, Ankara, s.619.

Atasoy, N., Mercan, U., Alacabey, i. \& Kul, A. R. (2011). Van şehir merkezindeki içme ve musluk suyunda bulunan ağır metaller ve bazı makro element seviyeleri, Hacettepe J Biol. \& Chem, 39(4), 391-396.

Avşarer, B., Tüfekçi, N., Elmaslar, E. \& Şahin, Ü. (2005). Mangan (II)'ın oksijenle oksidasyonuna inorganik ve organik maddelerin etkisi, Ulusal Su Günleri 2005, 28-30 Eylül 2005, Trabzon.

Babur E. (2019). Effects of parent material on soil microbial biomass carbon and basal respiration within young afforested areas. Scaninavian Journal of Forest Research, 43(2):94-101. [CrossRef]

Babur, E. \& Dindaroğlu, T. (2020). Seasonal Changes of Soil Organic Carbon and Microbial Biomass Carbon in Different Forest Ecosystems, In: Environmental Factors Affecting Human Health. [CrossRef]

Babur, E. \& Kara, Ö. (2017). Su Kalitesi ve Orman Toprakları Arasındaki Illişkiler. 2nd International Water and Health Congress. Şubat 2017, Antalya.

Bernal, S., Butturini, A., Nin, E., Sabater, F. \& Sabater, S. (2003). Leaf litter dynamics and nitrous oxide emission in a Mediterranean riparian forest Implications for soil nitrogen dynamics. J Environ Qual, 32, 191-197. [CrossRef]

Blanco, J. A. \& Lo, Y. H. (2012). Forest Ecosystems- More Than Just Trees. Janeza Trdine 9, 51000 Rijeka, Croatia, ISBN 978-953-51-0202-1.

Bulut, C., Atay, R., Uysal, K., Köse, E. \& Çınar, Ş. (2010). Ulubat Gölü Yüzey Suyu Kalitesinin Değerlendirilmesi. Aquatic Sciences and Engineering, 25(1), 9-18.

Bussiere, F. \& Cellier, P. (1994). Modification of the soil temperature and water content regimes by a crop residue mulch: experiment and modeling. Agr Forest Meteorol, 68, 1-28. [CrossRef]

Costanza, R. \& Jorgensen, S. E. (2002). Understanding and Solving Envionmental Problems in the 21st Century. Elsevier, first edition. ISBN: 0-08-044111-4

Cummins, K. W., Sedell, J. R., Swanson, E. J., Minshall, G. W., Fisher, S. G., Cushing, C. E., Peterson, R. C. \& Vannote, R. L. (1983). Organic matter budgets for stream ecosystems: problems in their evaluation. In: Barnes JR, Minshall GW (eds) Stream ecology: application and testing of general ecological theory. Plenum Press, New York, pp 299-353. [CrossRef]

Çetinkaya, O. (2003). Su Kalitesi Ders Notları, Yüzüncü Yıl Üniversitesi Ziraat Fakültesi Su Ürünleri Bölümü. Van, 76 s.

Environmental Protection Agency (EPA) METHOD 200.7. (2001). Determination of metals and trace elements in water and wastes by inductively coupled plasma-atomic emission spectrometry. https:// www.epa.gov/ (accessed 03.03.2019).

Dorney, J. R. (1986). Leachable and total phosphorous in urban street tree leaves. Water Air Soil Poll, 28, 439-443.

Duan, S. W., Amon, R. M. W. \& Brinkmeyer, R. L. (2014). Tracing sources of organic matter in adjacent urban streams having different degrees of channel modification. Sci Total Environ, 485-486, 252-262. [CrossRef]

Gerrits, A. M. J., Savenije, H. H. G., Hoffmann, L. \& Pfister, L. (2007). New technique to measure forest floor interception - an application in a beech forest in Luxembourg. Hydrol Earth Syst Sci, 11, 695-701. [CrossRef]

Gerrits, A. M. J, Pfister, L. \& Savenije, H. H. G. (2010). Spatial and temporal variability of canopy and forest floor interception in a beech forest. Hydrol Process, 24, 3011-3025. [CrossRef]

Göksu, M. Z. L. (2003). Su Kirliliği, Çukurova Üniversitesi Su Ürünleri Fakültesi Yayınları, No:7, Adana, s. 232.

Grey, W. Gene-Deneke. \& Frederic, J. (1986). "Urban Forestry". John Mille and Sons, New York: Wiley c1986. ISNB 0-89464-704-0.

Gülçür, F., (1974). Toprağın Fiziksel ve Kimyasal Analiz Metodları. i.ü. Yayınları Yay No: 1970, Orman Fak. Yay. No: 201. Kurtuluş Matbaası, İstanbul. 
Güler, Ç. (1997). Su Kalitesi Kitabı, Çevre Sağlığı Temel Kaynak Dizisi, 1. Baskı, s. 92, Ankara.

Kahraman, T., Alemdar, S., Alişarlı, M. \& Ağaoğlu, S. (2012). Bitlis ili içme sularında ağır metal düzeyleri. Eurasian Journal of Veterinary Sciences, Seul, 28(3), 164-171.

Kara, Ö., Babur, E., Altun, L. \& Seyis, M. (2016). Effects of afforestation on microbial biomass $C$ and respiration in eroded soils of Turkey. $J$ Sustain For, 35(6), 385-396. [CrossRef]

Kantarcı, M. D. (2003). Toprak Illmi Ders Kitabı. I.Ü. Orman Fakültesi, 80895 Bahçeköy, İstanbul.

Li, X., Niu, J. \& Xie, B. (2013). Study on Hydrological Functions of Litter Layers in North China. PLoS ONE, 8(7), e70328. [CrossRef]

Lundberg, A., Eriksson, M., Halldin, S., Kellner, E. \& Seibert, J. (1997). New approach to the measurement of interception evaporation. J Atmos Ocean Tech, 14, 1023-1035. [CrossRef]

Meyer, J. L., Wallace, J. B., \& Eggert, S. L. (1998). Leaf litter as a source of dissolved organic carbon in streams. Ecosystems, 1, 240-249. [CrossRef]

Muria, S. (2000). Proposals for a new definition to evaluate the status of forest floor cover and floor cover percentage (FCP) from the viewpoint of the protection against raindrop splash. J Japan Forestry Soc, $82,132-140$.

Newbold, J. D., Elwood, J. W., Schulze, M. S., Stark, R. W. \& Barmeier, J. C. (1983). Continuous ammonium enrichment of a woodland stream: uptake kinetics, leaf decomposition, and nitrification. Freshw Biol, 13, 193-204. [CrossRef]
Özhan, S. (2004). Havza Amenajmanı, İstanbul Üniversitesi Orman Fakültesi Yayın No: 481, İstanbul, 384.

Pitman, J. I. (1989). Rainfall interception by bracken litter-Relationship between biomass, storage and drainage rate. J Hydrol, 111, 281-291. [CrossRef]

Putuhena, W. \& Cordery, I. (1996). Estimation of interception capacity of the forest floor. J Hydrol, 180, 283-299. [CrossRef]

Sato, Y., Kumagai, T., Kume, A., Otsuki, K. \& Ogawa, S. (2004). Experimental analysis of moisture dynamics of litter layers - the effect of rainfall conditions and leaf shapes. Hydrol Process, 18, 3007-3018. [CrossRef]

Sayer, E. J. (2006). Using experimental manipulation to assess the roles of leaf litter in the functioning of forest ecosystems. Biol Rev, 81, 1-31. [CrossRef]

Tobon-Marin, C., Bouten, I. W. \& Sevink, J. (2000). Gross rainfall and its partitioning into throughfall, stemflow and evaporation of intercepted water in four forest ecosystems in western Amazonia. J Hydrol, 237, 40-57. [CrossRef]

Tokatli, C., Solak, C. N., \& Yılmaz, E. (2020). Water quality assessment by means of bio-indication: A case study of ergene river using biological diatom index. Aquatic Sciences and Engineering, 35(2), 43-51. [CrossRef]

TSE. (1997). TS-266, Türk İçme Suyu Standartları, Türk Standartları Enstitüsü, Ankara.1997. 